\title{
DYNAMICS OF FIRM'S CAPITAL STRUCTURE ALONG THE LIFE CYCLE OF INDONESIAN MANUFACTURING FIRMS
}

\author{
Erika Putri Cempakasari")1, Muhammad Firdaus ${ }^{* *)}$, and Arief Tri Hardiyanto $\left.{ }^{* * *}\right)$ \\ *) School of Business, Bogor Agricultural University \\ SB IPB Building, Pajajaran Road, Bogor 16151 \\ **) Departement of Economics, Faculty of Economics and Management, Bogor Agricultural University \\ Jl. Agatis, Campus of IPB Darmaga Bogor 16680 \\ ${ }^{* * *)}$ Pakuan University \\ Jl. Pakuan PO Box 452 Bogor 16143
}

\begin{abstract}
Life cycle of the firm has an important role in the dynamics of firm's capital structure. A firm will take different funding decision along the life cycle because the firm's characteristics that affect the capital structure will adjust itself as the tranformation of the life cycle occuring. The research objectives were to analize the dynamic of firm's capital structure across three-life cycle stages of Indonesian manufacturing companies listed with a total sample of 121 companies observed during the period from 2011 to 2016. By using dynamic panel data analysis with Generalized Method of Moments (GMM) model, we find that profitability and liquidity affect the firm's life cycle for a growing stage, meanwhile the fixed asset, growth opportunities, profitability, and liquidity affect the capital structure for a mature stage, whereas only liquidity that affects capital structure for a decline stage. The coefficient of lag dependent variable of GMM model representing the previous year capital structure showed an adjustment rate of capital structure. The lowest speed of adjustment occurred on the decline stage which was orderly followed by the growth and mature stage.
\end{abstract}

Keywords: capital structure, life cycle of firm, firm's characteristics, dynamic panel data analysis

\begin{abstract}
Abstrak: Siklus hidup perusahaan memiliki peranan penting dalam dinamika struktur modal suatu perusahaan. Perusahaan akan memiliki keputusan pendanaan yang berbeda pada setiap siklus hidupnya, karena karakteristik perusahaan yang mempengaruhi struktur modal akan berubah mengikuti perkembangan siklus hidup yang terjadi. Tujuan dari penelitian ini menganalisa dinamika struktur modal perusahaan selama tiga tahap siklus hidup yang terjadi pada perusahaan manufaktur go public di Indonesia, dengan total jumlah 121 perusahaan yang diamati selama periode 2011-2016. Dengan pengolahan data yang dilakukan dengan analisis data panel dinamis dengan model Generalized Method of Moments (GMM), kami menemukan bahwa variabel yang berpengaruh pada siklus hidup growth adalah profitabilitas dan likuiditas perusahaan. Berbeda halnya pada siklus hidup mature, variabel yang memiliki pengaruh signifikan terhadap struktur modal adalah aset tetap, pertumbuhan, profitabilitas, dan likuiditas perusahaan. Sementara pada siklus hidup decline, variabel yang memiliki pengaruh signifikan terhadap struktur modal adalah likuiditas perusahaan. Nilai koefisien lag variabel terikat pada model GMM yang mewakili struktur modal tahun sebelumnya menggambarkan kecepatan perusahaan dalam menyesuaikan struktur modalnya. Tingkat kecepatan penyesuaian struktur modal terendah ada pada siklus hidup decline yang diikuti berturut-turut oleh perusahaan yang berada pada siklus hidup growth dan siklus hidup mature.
\end{abstract}

Kata kunci: struktur modal, siklus hidup perusahaan, karakteristik perusahaan, analisis data panel dinamis

\footnotetext{
${ }^{1}$ Corresponding author:

Email: ptrc.erika@gmail.com
} 


\section{INTRODUCTION}

Capital is one of the important components of a firm as the addition of the human resources, machines, and technology. By the sufficient capital firm may unimpeded run its business operational. Especially when the firm is going to expand its business as the effort to produce competitive advantage among business competitions in globalization era. It is, therefore, the funding decision management becomes fundamental. It occurrs because funding decision related to the firm's capital structure will determine the firm's value in the future, which will affect the shareholders' welfare as the main purpose of the firm establishment.

Mardiyanto (2009) says that the decision of firm's capital structure is the funding decision related to the long term funding composition obtained through the debt issuance or owner's equity. Firm must be able to collect funds from anywhere outside of the firm efficiently, that is a condition in which the funding composition can minimize the capital cost which should be borne by the firm (Prabansari and Kusuma, 2005). The capital cost is the cost incurred as the consequence of the funding decision taken by the firm.

The theory of capital structure has been continually developed since Modigliani and Miller published their study in 1958. As cited on Brigham et al. (2006), at the time Modigliani and Miller introduce the irrelevance theory which states that the funding decision composition of firm will not give any effect toward the firm's value. However, when they conducted a study again in 1963, Modigliani and Miller revised their previous theory by saying that the firm's value may be affected by the capital structure involving the calculation of firm tax factors obtained from the use of debt.

It is in line with the trade-off theory which states that the firm's capital structure is the trade-off result between the tax profits of the debt use with the cost incurred due to the debt use. Trade-off theory confirms the existence of the optimal capital structure of firm, as stated by Myers (2001) that firm will owe to a certain level of debt, in which the tax savings from the additional debt is equal to the cost of financial distress and agency cost. The financial distress come up due to the excessive use of debt in the firm's capital structure, which eventually may cause the increase of bankruptcy risk. On the other hand, the agency cost is the cost come up due to the decrease of the credibility of such firm.
Martono and Harjito (2003) argue that the optimal capital structure meant as the capital structure that may minimize the entire capital cost or the average capital cost. Thus this will maximize the firm's value. When the capital cost can be minimized then the potential of dividend payment may increase so that the share's price will also increase. According to Walker (2000), the price of firm share basically is an indicator that can be used to measure the firm's value as the measurement of the firm performance.

Optimal capital structure of firm is the ideal leverage level owned by every firm because the leverage of firm will affect the profits per share, the risks level, and the share price. Although the deviation of ideal leverage level often occurs in the journey of such business, but eventually the firm gradually make adjustment from time to time leading to the optimal capital structure. According to Byoun (2008) most of firm will make adjustment the capital structure when a firm has debt over the target with condition of financial surplus or when it has debt under the target with the condition of financial deficit.

A study about the level of optimal capital structure of firm has been conducted by several previous researchers using capital structure static method. However there are some focuses of the study often neglected in the frame of capital structure static as stated by Heshmati (2001) that the previous researchers only measure the actual leverage level used as the proxy of optimal capital structur so that the deviation possibility from the optimal leverage is high. In addition, the frame of capital structure static also cannot get the dynamic occurring in the firm environment that always change so that this cannot measure the change occurring due to the adjustment of actual capital structure toward the target capital structure as conducted by the firm every year happening in the real life.

To settle the problem, the study of optimal capital structure has been developed by using dynamic model. Although the optimal leverage level of firm cannot be measured directly (unobservable), the dynamic model may predict using leverage ratio observed as the proxy of the leverage target with the affected factors, that is, the specific characteristic of firm such as profitability, investment chance, tangibility of assets, and profits volatilities (Titman and Wessels, 1988). Moreover, the dynamic model can also measure the speed of the firm adjustment in giving reaction toward the change 
of the capital structure leading to the optimal capital structure.

The life cycle of firm has an important role in the dynamic of capital structure of a firm. It will have different funding decision in every life cycle because the characteristic of firm affecting the capital structure will adjust to the development of life cycle occurring. Frielinghaus et al. (2005) find the correlation between the capital structure and firm's life cycle and show that the analysis of firm's life cycle has a practical use in firm so that the financial practitioner of firm try to comprehend the stage of the life cycle of such firm with the aim to understand the capital structure need in accordance with the firm's condition.

The financing strategy of firm may change along with the transition of firm which recently becomes a mature firm until it has a decrease eventually (Damodaran, 2001). The life cycle of firm based on the economical theory has four stages. Those are the first stage (startup), the growth stage (growth), the defense stage (maturity) and the decrease stage (decline). Sometime a firm only reaches the critical point of growth or maturity but then it declines. Even several companies that currently reach the stage of introduction may have the decline without the growth stage.

In the first stage of life cycle, a firm doesn't have a big asset to be the warranty of debt on the third party. Their income is still considered low to utilize the profit of tax deduction. The more a firm grows and develops, the more it has increase in profits, fixed assets and the firm size that can reduce the bankruptcy costs although the growth of firm may cause in reverse. Based on that fact, it is considered that the life cycle of firm has an important role in determining the capital structure of a firm.

One of the studies classified the life cycle of the firms which had been ever conducted by Anthony and Ramesh (1992). The method they used gives a direction that the stage of life cycle is higher, which is indicated by the increase of sales growth and the decrease of dividend payout. However, the dividend payout may be low because the firm has a long time in industry and at present it is in the difficulty of liquidity, so that it is included into the variable of age of firm to minimize the possibility of classification error of firm into its life cycle.
The dynamic of optimal capital structure with the specific characteristic that affect the various life cycle of a firm has been studied by some researchers previously. Castro et al. (2016) has conducted a study by dividing the companies in Europe into three stages of cycle, namely introduction, growth, and mature. Meanwhile, the study of Rehman et al. (2016) uses sample of non financial firm of China divided into three stages of cycle, namely growth, mature and decline. Similar characteristics measured on both studies in finding the determinant of optimal capital structure are fixed assets, profitability, liquidity, firm size, and the growth opportunities.

A firm with high proportion of fixed assets is expected to facilitate the firm itself in obtaining the funding from outside. Therefore, the higher the firm's assets, the more the leverage level of firm predicted. The positive relation of the fixed assets with leverage is found in Castro et al. (2016) on the stage of introduction, growth, and matures.

Profitability is the ability of firm in producing profits during a year. Pecking order theory says that the higher the profitability of firm, the lower the level of leverage. Castro et al. (2016) find negative relationship between the profitability and leverage on the stage of introduction, growth, and mature. As well as Rehman et al. (2016) find the negative relationship on the stage of growth, mature, and decline.

The profitability level of firm is usually direct proportional to the liquidity level, in which the higher the profitability of firm, the more liquid cash level or current assets. When the liquidity level of firm is high, then the lower debt is needed by the firm. Castro et al. (2014) does not find the significant relationship between the liquidity and leverage on the stage of growth, but there is a negative relationship on the stage of shake-out. Meanwhile, Rehman et al. (2016) find the significant negative relationship on all stage of growth, mature, and decline.

A big firm commonly has stable cash flow with a better resilience toward the bankruptcy risk than the small firm. It is in line with trade-off theory which expects the leverage level become bigger along with the high of firm size. Castro et al. (2016) find positive relationship occurring on the stage of growth and mature, but it is the reverse on the stage of introduction. 
The growth of firm indicates the number of the investment needs that can be funded internally. It is in accordance with pecking order theory where the level of leverage will increase when investment opportunities that are available may not enough to be funded from the internal funding of firm (Wijayanti, 2012). The study conducted by Castro et al. (2016) show the positive relationship of the firm's growth only found in the stage of mature while on the stage of introduction and growth this gives a negative relationship.

In Indonesia, there are many studies about capital structure which has been conducted. Noor et al. (2015) find that in determining the company's capital structure policy, agricultural companies have implemented the concept of the pecking order theory which indicates that the internal funding deficit has a significantly positive effect on the company's long-term debt changing. However, the study which proves the correlation of the life cycle toward the optimal capital structure of firm in Indonesia is less. Therefore, the researcher is interested in adapting the study conducted by Castro et al. (2016) and Rehman et al. (2016) by taking sample of Indonesian manufacturing firms. The dynamic model used also explains the speed of firm in every cycle in adjusting the capital structure leading to the optimal capital structure. Based on the background explained above, this study tried to analize the dynamic of firm's capital structure across three life cycle stages of listed Indonesian manufacturing companies, with a total sample of 121 companies observed during the period from 2011 to 2016.

\section{METHODS}

This study observed the determinant of optimal capital structure with the adjustment speed measured across the life cycle of firm listed in manufactures sector of Stock Exchange of Indonesia (BEI). The measurement of determinant and speed adjustment of capital structure use dynamic model with Partial Adjustment Model (PAM) as referred to Hardiyanto (2014) using the firm's characteristics, namely fixed assets, firm size, growth opportunity, profitability, and liquidity as determinant variables. Moreover, the sample classification based on the life cycle referred to Anthony and Ramesh (1992). All data used on the analysis was secondary data that is the financial report data of firm taken from Indonesia Data Exchange (IDX).
The first step of study was conducting sample classification into three stages of life cycle, namely growth, mature, and decline. The measurement of the cycle referred to the method used by Anthony and Ramesh (1992). Sample observation classification covered the stage of growth, mature, and decline which was conducted based on the classification indicators, namely dividend payout (DP), sales growth (SG), age of firm (AGE), and capital expenditure (CEV). According to Anthony and Ramesh (1992), generally the more mature a firm, the higher the dividend payment ratio and the lower the growth change and capital expense. However, the low dividend payment may occur on the old firm in industry, and it has difficulty in liquidity so that this put into the variable of age to minimize the possibility of classification error into its life cycle. Shortly, the classification indicators of three stages of cycle are shown in the Table 1 .

The classification in Table 1 is carried out on an annual basis where the data of each indicator for all companies is sorted and divided into five quintiles. Each quintile of each indicator will be scored based on the industry quintile ranking. Quintile partition was meant to divide the observed firm into three stages of life cycle of firm. The value score of each variable based on the industrial quintile can be seen on Table 2 .

Table 1. Classification indicators of cycle of growth, mature, and decline

\begin{tabular}{lcccc}
\hline Life cycle & \multicolumn{4}{c}{ Classification indicator of firm's life cycle } \\
\cline { 2 - 5 } stage of firm & DP & SG & AGE & CEV \\
\hline Growth & Low & High & Young & High \\
Mature & Medium & Medium & Mature & Medium \\
Decline & High & Low & Old & Low \\
\hline
\end{tabular}

Source: Anthony and Ramesh (1992)

Table 2. Score of classification indicators of firm's life cycle based on the industrial quintile

\begin{tabular}{ccccc}
\hline Industrial & \multicolumn{4}{c}{ Classification indicators of firm's life cycle } \\
\cline { 2 - 5 } Quintile & AGE & SG & CEV & DP \\
\hline $80-100 \%$ & 1 & 5 & 5 & 3 \\
$60-80 \%$ & 2 & 4 & 4 & 3 \\
$40-60 \%$ & 3 & 3 & 3 & 3 \\
$20-40 \%$ & 4 & 2 & 2 & $4(2)^{*}$ \\
$0-20 \%$ & 5 & 1 & 1 & $5(1)^{*}$ \\
\hline
\end{tabular}

${ }^{*}$ If the total score of AGE, SG, and CE low (less than 7.5), then the score of DP used is the lowest (1 or 2). Source: Etemadi and Mougouie (2015). 
The addition results of composite score of four indicators have a score range between four to twenty. The classification of the three stages of life cyce of a firm in every year is based on the total of composite score: Stage "GROWTH": the total combined score between 16 and 20; Stage "MATURE": the total combined score between 9 and 15; Stage "DECLINE": the total combined score between 4 and 8 .

The dynamic model of a capital structure is used in this study in predicting that every firm has a tendency to adjust the capital structure toward the target, that is, the optimal capital structure that gives an optimum value for the firm. According to Frank and Goyal (2009), the capital structure target cannot be observed so that this target should be estimated. When the optimal capital structure estimation can be known, then the speed of the adjustment can also be measured. By using the panel data which are the combination of time series data and cross section. The analysis of capital structure dynamic model was conducted using Partial Adjustment Model (PAM).

On this study, the estimation target of capital structure was referred to Drobetz and Wanzenried (2006). The study shows that the target of capital structure or optimal capital structure is made based on the characteristics of firm. The reference model depicts the optimal capital structure or target on i firm in n year, symbolized with $\mathrm{LV} *$ it is the linear function from $\mathrm{L}$ variable of firm's characteristic Xjit (where $\mathrm{j}=1,2, \ldots ., \mathrm{L}$ ).

$$
\mathrm{LV}_{\mathrm{it}}^{*}=\sum_{\mathrm{j}=1}^{\mathrm{L}} \mathrm{a}_{\mathrm{j}} \mathrm{X}_{\mathrm{jit}}
$$

On this study, the firm's characteristics used the explanatory variables, that is, fixed asset (TANG), firm size (SIZE), growth opportunities (GROWTH), profitability (PROF), and liquidity (LIQ). Therefore, the equation (1) can be depicted into the model below:

$$
\begin{aligned}
& \mathrm{LV}_{\mathrm{it}}^{*}=\alpha+\mathrm{a}_{1} \mathrm{TANG}_{\mathrm{it}}+\mathrm{a}_{2} \mathrm{SIZE}_{\mathrm{it}}+\mathrm{a}_{3} \mathrm{GROWTH}_{\mathrm{it}}+ \\
& \mathrm{a}_{4} \mathrm{PROF}_{\text {it }}+\mathrm{a}_{5} \mathrm{LIQ}_{\mathrm{it}}+\mu_{\mathrm{it}}
\end{aligned}
$$

Warmana and Widnyana (2016) say that in the environment without friction, the firm will automatically adjust its capital structure (LV) toward target. It may produce that the capital structure observed will be the same with the target, that is, the optimal capital structure. However, by the adjustment cost, firm may not change as complete as the target. The change of capital structure inter-firm and inter-time can be explained by the following equation:

$$
\left(\mathrm{LV}_{\mathrm{it}}-\mathrm{LV}_{\mathrm{it}-1}\right)=\delta\left(\mathrm{LV}_{\mathrm{it}}^{*}-\mathrm{LV}_{\mathrm{it}-1}\right)
$$

The adjustment speed $(\delta)$ is varies between zero to one, inversely related to the cost of adjustment. When the score of adjustment speed is getting closer to one, the firm is getting closer to optimal capital structure. Vice versa, when the score is getting closer to zero, then the capital structure of firm is getting far from the optimal capital structure. The equation (3) can be simplified by moving the score of capital structure a previous year to the right part, as explained below:

$$
\mathrm{LV}_{\mathrm{it}}=\delta \mathrm{LV}_{\mathrm{it}}^{*}+(1-\delta) \mathrm{LV}_{\mathrm{it}-1}
$$

By doing substitution to the equation (2) into the equation (4), then this will produce new equation as follows:

$$
\begin{aligned}
\mathrm{LV}_{\mathrm{it}}= & \delta\left[\alpha+\mathrm{a}_{1} \text { TANG }_{\mathrm{it}}+\mathrm{a}_{2} \operatorname{SIZE}_{\mathrm{it}}+\mathrm{a}_{3} \text { GROWTH }_{\mathrm{it}}+\right. \\
& \left.\mathrm{a}_{4} \text { PROF }_{\mathrm{it}}+\mathrm{a}_{5} \mathrm{LIQ}_{\mathrm{it}}+\mu_{\mathrm{it}}\right]+(1-\delta) \mathrm{LV}_{\mathrm{it}-1} \ldots \ldots . . .(5)
\end{aligned}
$$

Through the equation above it is clearly illustrated the group of variables from each component. Details about the definitions and measurements of each variable can be seen in Table 3 .

Equation (5) is analyzed by using the Generalized Method of Moments (GMM) model. GMM is a good model in analyzing the dynamic panel data because this may produce the consistence estimation parameter although there is a problem of heterocedacity. Baltagi (2005) says that the regression model of best dynamic panel data require that the estimator should be not bias, valid, and consistent. Bias test can be conducted by comparing the coefficient score of the first lag of independent variable from the Sys-GMM model with Pooled Least Square (PLS) model and Fixed Effect Model (FEM). Meanwhile, the validity test was conducted by doing Sargan test and consistency test through Arellano-Bond test.

\section{RESULTS}

On this study all samples of firms were classified based on the life cycle in the form of the stage of growth, mature, and decline. The indicators of dividend payout 
(DP), sales growth (SG), firm age (AGE), and capital expenditure (CEV) were used because the variables may depict the stage position of a firm. The average score of indicator variables on various stage of cycle of a firm based on the sample classification result can be seen on the Table 4.

The descriptive above shows that the firms on the stage of growth indicated the age of firm is quite young and started to be known largely. Furthermore, this has high growth of selling and capital expense with tendency of low dividend payment level. The firms that are on the mature stage which have older age than the firm in growth have lower growth of selling and capital expense with high dividend payment level. Otherwise, the firms on the decline stage are older than the others, with the tendency of the weaken growth of selling and capital expense, but they still have a higher dividend payment level than the firms on the growth stage.

The above explanation is in accordance with the statement of Anthony and Ramesh (1992) except for the dividend payment level, in which they say that the lowest dividend payment level will be owned by the firm in the stage of growth followed by the firm in stage of mature. Then the higher dividend payment level belongs to the firm in the stage of decline. The low of dividend payment level paid by the firm on the stage of growth was related to the funding issues, where commonly a firm in this stage tends to use its own budget to invest, particularly capital goods in order to increase the market share. Meanwhile, the high of dividend payment level of firm in the mature stage on this study which may be caused by the chance of the firm to develop was low and the profit level earned has been high so that the firm tend to pay the dividend. As stated by Deangelo et al. (2006) that dividend tend to be paid by the firm in the stage of mature, because the firm in the stage of growth commonly has high business chance so that it tends to keep their profit. The retained earnings will be continually accumulated, so that on the mature stage, when there is no more business chance, the retained earnings are high, so then the firm does the dividend payment.

The regression model of dynamic panel data is not bias if the result of lag coefficient of dependent variable is produced by Sys-GMM between lag of dependent variable produced by FEM and PLS. Table 5 shows the bias test result with the comparison of three regression models of dynamic panel data on various life cycle.

Table 3. Definition and measurement of variables used in dynamic models

\begin{tabular}{|c|c|c|}
\hline Variables & Definition & Measurement \\
\hline \multicolumn{3}{|l|}{ Dependent Variable: } \\
\hline Leverage (LV) & $\begin{array}{l}\text { The amount of debt used in the funding } \\
\text { structure of a company }\end{array}$ & Total Leverage $=($ Total Debt $) /($ Total Asset $)$ \\
\hline \multicolumn{3}{|l|}{ Independent Variable: } \\
\hline Tangibility (TANG) & Tangible assets used in company operations & Tang $=($ Fixed Asset $) /($ Total Asset $)$ \\
\hline Company size (SIZE) & $\begin{array}{l}\text { The size of the company referred to total } \\
\text { assets }\end{array}$ & Size $=\ln$ Total Asset \\
\hline Company growth (GROWTH) & The company's ability to increase sales & GROWTH $=\left(\right.$ Sales $_{t}-$ Sales $\left._{t-1}\right) /$ Sales $_{t-1}$ \\
\hline Profitability (PROF) & The company's ability to make a profit & $\mathrm{ROA}=($ Net Profit $) /($ Total Asset $)$ \\
\hline Liquidity (LIQ) & $\begin{array}{l}\text { The company's ability to pay back current } \\
\text { debt }\end{array}$ & LIQ $=($ Current Asset $) /($ Current Liability $)$ \\
\hline
\end{tabular}

Table 4. Average score of the indicator every cycle of firm

\begin{tabular}{cccccc}
\hline \multirow{2}{*}{ Life sycle stage } & \multirow{2}{*}{ Number of Observation } & \multicolumn{3}{c}{ Mean } \\
\cline { 3 - 6 } & & DP & SG & AGE & CEV \\
\hline Growth & 64 & 8.7693 & 61.2399 & 23.25 & 0.2703 \\
Mature & 503 & 23.9684 & 13.0336 & 36.98 & 0.0755 \\
Decline & 121 & 10.5236 & -11.7411 & 40.69 & -0.0986 \\
\hline
\end{tabular}


From Table 5 it can be known that estimator with SysGMM approach on all life cycle of growth, mature, and decline is not bias and right to be used because the lag coefficient of dependent variable of Sys-GMM model is bigger than the coefficient of FEM model and smaller than the coefficient of PLS model. It is in accordance with the statement of Baltagi (2005) that lag coefficient of dependent variable produced by PLS will be bias up, while the lag coefficient of dependent variable produced by FEM will be bias down. Next for the validity test and consistency test of panel data regression of SysGMM model can be seen on the Table 6 .

Validity test of Sys-GMM model through Sargan test stated that the instrument will be valid if the test result does not deny the zero hypothesis ( $\mathrm{H} 0$ : probability $>$ chi2). The test result of Sargan on Table 6 shows that the probability score on all life cycle of growth, mature, and decline was bigger than $\alpha 5 \%$. This means that the score does not deny the zero hypotheses so that the instrument through the Sys-GMM approach is stated as valid and has been well specified. ArrelanoBond test used as the consistency test on Sys-GMM model. This will indicate that there is no problem of autocorrelation serial if the AR (2) result does not deny the zero hypothesis ( $\mathrm{H} 0$ : probability $>\mathrm{z}$ ). According to Mileva (2007), AR (1) commonly score will deny the zero hypothesis although no matter if this cannot be reached, because the one that can detect the autocorrelation serial is AR (2) score. Table 5 shows the AR (2) score on life cycle of growth, mature, and decline which is bigger than $\alpha 5 \%$ so that this does not deny the zero hypothesis in which this means that there is no serial autocorrelation in Sys-GMM approach thus the model is feasible to be used.

After the estimator with Sys-GMM approach is stated to be unbiased, valid, and consistent, then the hypothesis test result to estimate the influence of independent variable toward the dependent variable can be analyzed. Independent variables are the characteristic of firm in the form of TANG (fixed assets), SIZE (firm size), GROWTH (growth opportunities), PROF (firm profitability), and LIQ (firm liquidity) whereas the dependent variable is LV (total of leverage) as the proxy of capital structure. The estimation result using Sys-GMM model can be seen on Table 7 .
The results of the influences analysis obtained show that for the significant relationship of fixed assets variable can only be found in the life cycle of mature stage with the significance at the $1 \%$ level. The negative relationship can be seen from the coefficient value of -0.3361 which indicates that an increase of one unit of fixed asset in the mature stage, ceteris paribus will make the leverage value decrease to 0.3361 . Meanwhile, the firm on the life cycle of growth and decline has no significant influence. This result is different from the research conducted by Rehman et al. (2016) which found positive relationship of fixed assets toward the capital structure of Chinese companies in the decline stag but not in the growth and mature stage. In contrast to Castro et al. (2016) who found a positive relationship offixed assets in the entire stage of European companies. The negative influences of fixed assets on the mature stage occurring on this study is possible because the characteristics of firm on this stage has reached the top income level and high liquidity level. In accordance with pecking order theory, the firm on this stage tended to choose the internal funding source to reduce the risk that may be emerged from the making of new debt policy which affected the lower assets structure used as the warranty to get debt causing the decrease of capital structure.

Table 5. Bias test result of dynamic panel data on various life cycles

\begin{tabular}{lccc}
\hline \multirow{2}{*}{$\begin{array}{l}\text { Regression } \\
\text { Model }\end{array}$} & \multicolumn{3}{c}{ Lag coefficient of dependent variable } \\
\cline { 2 - 4 } & Growth & Mature & Decline \\
\hline Sys-GMM & 0.6483 & 0.5807 & 0.8030 \\
FEM & 0.1679 & 0.2649 & 0.3278 \\
PLS & 0.7251 & 0.8225 & 0.8719 \\
\hline
\end{tabular}

Table 6. Validity and Consistency test result of SysGMM on various life cycles

\begin{tabular}{lccc}
\hline Type of & \multicolumn{3}{c}{ Prob $>$ chi2 } \\
\cline { 2 - 4 } the test & Growth & Mature & Decline \\
\hline Validity test & 0.088 & 0.064 & 0.096 \\
(Sargan Test) & & & \\
Consistency test & $\mathrm{AR}(1):$ & $\mathrm{AR}(1):$ & $\mathrm{AR}(1):$ \\
& 0.157 & 0.013 & 0.090 \\
(Arellano-Bond & $\mathrm{AR}(2):$ & $\mathrm{AR}(2):$ & $\mathrm{AR}(2):$ \\
Test) & 0.154 & 0.201 & 0.368 \\
\hline
\end{tabular}


Table 7 Estimation result of Sys-GMM method on various stage of life cycles

\begin{tabular}{lcccccc}
\hline \multirow{2}{*}{ Variable } & \multicolumn{2}{c}{ Growth } & \multicolumn{2}{c}{ Mature } & \multicolumn{2}{c}{ Decline } \\
\cline { 2 - 6 } & Coefficient & P-Value & Coefficient & P-Value & Coefficient & P-Value \\
\hline LV $_{\mathrm{t}-1}$ & 0.6483 & 0.000 & 0.5807 & 0.000 & 0.8030 & 0.000 \\
TANG & -0.0365 & 0.685 & -0.3361 & 0.000 & 0.0621 & 0.538 \\
SIZE & -0.0060 & 0.749 & 0.0143 & 0.319 & -0.0106 & 0.284 \\
GROWTH & 0.1154 & 0.257 & 0.0322 & 0.036 & 0.0279 & 0.816 \\
PROF & -0.6532 & 0.002 & -0.4054 & 0.000 & 0.0907 & 0.626 \\
LIQ & -0.0197 & 0.022 & -0.0485 & 0.000 & -0.0006 & 0.031 \\
\hline
\end{tabular}

The variable of firm size shows t-statistic probability value is higher than the value of alpha $(5 \%)$ on the life cycle of growth, mature, and decline. It indicates that the firm size is not proven in giving the significant influence toward all stages life cycle of firm. In contrast to the results in this study, Rehman et al. (2016) found a positive relationship of firm size toward firm's capital structure throughout the life cycle of Chinese companies.

The variable of growth opportunities proved to have a significant influence toward the capital structure but only in the mature stage of life cycle with the significance at the $5 \%$ level. The coefficient value of +0.0322 which indicates the positive relationship meaning that an increase of one unit of growth opportunities in the mature stage, ceteris paribus will cause the leverage increase to 0.0322 . Meanwhile, the growth opportunities on the life cycle of growth and decline have no significant influence. Similar result was also found in the study conducted by Rehman et al. (2016) in Chinese companies that are in the stage of growth and decline, but not in the mature stage. The positive relationship of growth opportunities toward the capital structure on mature stage in accordance with pecking order theory where there is very high investment opportunities at this stage which are not supported by the internal funding of firm. As well as the trade-off theory which states that the small volatility through the diversification may increase the firm chance to get profits so that it is predicted to have a positive relationship with leverage. Firms that have high growth will be easier to access the capital market because they have positive signals concerning the performance of firm in the future, besides that the firm can also maximize the profit of tax deduction on the use of debt.
The variable of profitability is seen to have a significant influence toward the capital structure of firm on the growth and mature stage cycle with the significance at the $1 \%$ level. Both stages of life cycles show a negative influence with various number of coefficients of PROF variable. Meanwhile, the firm on the life cycle of decline did not show any significant influence. The coefficient value of -0.6532 on the growth stage indicates that an increase of one unit of firm profitability, ceteris paribus may cause the leverage decrease to 0.6532 . Moreover, the coefficient value of -0.4054 on mature stage indicates that an increase of one unit of firm profitability, ceteris paribus will cause the leverage decrease to 0.4054 . The negative relationship of profitability toward firm's capital structure has also been found by Castro et al. (2016) in the entire stage of European companies, that is, introduction, growth, and mature stages. The profitability gives negative influence toward leverage because the higher profit produced by a firm with the retained earning produced also increase so that the firm needs in debt will reduce. It was in accordance with the implication of pecking order theory, where the firm with high profit tends to use the retained earnings as the source of firm funding and will use the debt in low number because the cost of internal funding was cheaper than the cost of external funding. Static tradeoff theory also supported this relation, where the more profitable firm tends to use the higher leverage because of the bigger tax protection. In addition, the profitable firm has lower bankruptcy risk, so that the possibility to increase the leverage is larger.

The liquidity influence toward the capital structure of firm on the this study was found on all stages of life cycle with the significance at the 5\% level for growth and decline stage while $1 \%$ level for the mature stage. All the life cycles show negative influence direction with various coefficient numbers. The coefficient value 
of -0.0197 on the growth stage shows an increase of one unit of firm liquidity, ceteris paribus will cause the leverage decrease to 0.0197 . For the firms in mature stage that has coefficient value of -0.0485 indicates that an increase of one firm liquidity, ceteris paribus will cause leverage decrease to 0.0485 . Meanwhile, the coefficient value of -0.0006 on the decline stage means that an increase of one unit of firm liquidity, ceteris paribus will cause the leverage decrease to 0.0006 . Similar results have been found in studies conducted by Rehman et al. (2016) which shows a negative and significant relationship of liquidity toward capital structure in all stages of European companies. The negative influence of liquidity toward the capital structure is in accordance with pecking order theory, where the firm with high liquidity level tends not to use the funding from debt. Because the firm has big internal fund so that the firm prefer to firstly use the internal fund for investment before using the external funding through debt.

Adjustment speed estimation of capital structure can be known from the lag coefficient value of dependent variable which represents the leverage level of firm a previous year (LVt-1). The speed of adjustment of the capital structure symbolized by $\delta$ will be obtained by reducing the number 1 with the lag coefficient value between $0-1$. Table 6 shows that the lowest adjustment speed level is on the decline stage with $19.70 \%$ per year, orderly followed by the growth stage with $35.17 \%$ per year and the mature stage with $41.93 \%$ per year. From those result it can be concludes that firms in the decline stage require more than five years in adjusting its capital structure, whereas the firms on the growth stage require about two years and eight months, and the firms on mature stage require the time for adjustment about two years and three months. Different results were obtained by Ahsan et al. (2016) which examine non-financial companies in Pakistan and Rehman et al. (2016) which examines non-financial companies in China. Both of them found that the highest adjustment speed is a company that is in the growth stage, which is followed by mature and decline respectively.

The adjustment speed of firm in adding the number of debt to reach the leverage target was affected by several factors either internal or external. The firms with low leverage level will try to increase the firm value by increasing the debt until optimal certain leverage level with high adjustment speed as owned by the firms in the mature stage on this study. Meanwhile, for the firms in decline stage, the adjustment speed is the lowest because on this stage the investment opportunities owned is lower than other stages so that they do not need to adjust their leverage soon.

\section{Managerial Implications}

Based on the analysis in proving important role of life cycle in the dynamics of the capital structure of a firm, the characteristics of the firm that continue to change along with the development of the life cycle that occurs is one of the important factors that influences the firm's capital structure. Therefore, it is important for firm's managers to know the cycle stage that is taking place in the company so that it becomes one of the considerations in determining the capital structure needs that are in accordance with the firm's circumstances. Changes in firm characteristics that occur along with the development of the firm's life cycle will provide an overview of the internal conditions of a firm. This can help the manager in formulating the right strategy in accordance with the condition of the company at that time. By knowing a number of factors that influence the firm's capital structure as well as an overview of the internal conditions that arise due to ongoing life cycle changes, a manager can easily decide an optimal capital structure. The characteristics that need to be concerned are profitability, liquidity, fixed assets, and growth opportunities because those characteristics have different influence on each firm's life cycle.

\section{CONCLUSIONS AND RECOMMENDATIONS}

\section{Conclusions}

Based on the results obtained in this study, it is proved that the life cycle of a firm has an important role in the dynamics of firm's capital structure. The firm's characteristics that change along with the development of the life cycle become one of the important factors affecting the firm's capital structure. The influences analysis of the firm's characteristics toward the capital structure show that on the growth stage, the variables of the firm's characteristics which have significant influence toward the capital structure are profitability and liquidity to a firm. It is different with the mature stage in which the variables of the firm's characteristics which have significant influence toward the capital structure are fixed assets, growth opportunities, profitability, and liquidity of firm. On the other hand, 
the decline stage of firm's life cycle, the variable of firm's characteristics which has a significant influence toward the capital structure is firm liquidity. In addition, the lag of dependent variable that represented the capital structure in the previous year is proved in giving influence toward the capital structure of firm on the growth, mature, and decline stage with coefficient value that may depict the speed of firm in adjusting the capital structure. The level of adjustment speed toward the lowest capital structure is the firms on the decline stage which is orderly followed by the firms in growth and mature stage.

\section{Recommendations}

Based on this research, the company's managers need to know the ongoing life cycle of the company. Because it will give an overview of the conditions faced by the company, thus the company can provide convenience in deciding the optimal capital structure strategy. The company will also have to be concerned with the characteristics of the firm such as profitability, liquidity, fixed assets, and growth opportunities because those characteristics have different influence on each company's life cycle. As for further research, classification of the firm's life cycle can be developed using the method proposed by Dickinson (2011), which considers the cash of operating, investing, and financing activities of the firm. Moreover, other research development can be conducted by adding the external factors that may influence the capital structure of firm, such as the interest rate, inflation level, exchange rate and many others, which then can give a complete conclusion about the influence toward the capital structure.

\section{REFERENCES}

Anthony J, Ramesh K. 1992. Association between accounting performance measures and stock prices. Journal of Accounting and Economics 15(2-3): 203-227. https://doi.org/10.1016/01654101(92)90018-W.

Baltagi BH. 2005. Econometric Analysis of Panel Data. New York: John Wiley \& Sons.

Brigham, Eugene F, Houston JF. 2006. Dasar-Dasar Manajemen Keuangan. Ed. Ke-10. Ali Akbar Yulianto, Penerjemah. Jakarta: PT. Salemba Empat.

Byoun S. 2008. How and when do firms adjust their capital structures toward targets? Journal Finance 63(6): 3069-3096. https://doi. org/10.1111/j.1540-6261.2008.01421.x.

Castro P, Fernandez MTT, Tapia BA, Miguel AD. 2016. Target leverage and speed of adjustment along the life cycle of European listed firms. Business Research Quarterly. 19: 188-205.

Castro P, Tascón MT, Tapia BA. 2014. The role of life cycle on the firm's capital structure. Pecvnia 19: 131-155. https://doi.org/10.1016/j. brq.2016.01.003.

Damodaran A. 2001. Corporate Finance: Theory and Practice. New York: John Wiley and Sons

DeAngelo H, DeAngelo L, Stulz RM. 2006. Dividend policy and the earned/conributed capital mix: a test of life cycle theory. Journal of Financial Economics 81: 227-284. https://doi. org/10.1016/j.jfineco.2005.07.005.

Dickinson V. 2011. Cash flow patterns as a proxy for firm life cycle. Accounting Review 86(6): 19691994. https://doi.org/10.2308/accr-10130.

Drobetz W, Wanzenried G. 2006. What determines the speed ofadjustment to the target capital structure? Applied Financial Economics 16(13): 941-958. https://doi.org/10.1080/09603100500426358.

Etemadi H, Mougouie FR. 2015. Firm's life cycle and ohlson valuation model: evidence from Iran. Asian Economic and Financial Review 5(4): 641-652. https://doi.org/10.18488/journal. aefr/2015.5.4/102.4.641.652.

Frank MZ, Goyal VK. 2009. Capital structure decisions: which factors are reliably important? Financial Management 38(1): 1-37.https://doi. org/10.1111/j.1755-053X.2009.01026.x.

Frielinghaus A, Mostert B, Firer C. 2005. Capital structure and the firm's life stage. South African Journal of Business Management 36(4): 9-18.

Hardiyanto, TH. 2014. Analisis determinan dan teori trade off struktur modal perusahaan masuk bursa di Indonesia. [dissertasi]. Bogor: Institut Pertanian Bogor.

Heshmati A. 2001. On the growth of micro and small firms: evidence from Sweden. Small Business Economics 17:213-228. https://doi.org/10.1023/ A:1011886128912.

Mardiyanto H. 2009. Inti Sari Manajemen Keuangan. Jakarta: Grasindo.

Martono, Harjito A. 2003. Manajemen Keuangan. Yogyakarta: Ekonisia.

Mileva E. 2007. Using Arellano-Bond Dynamic Panel GMM Estimators in Stata. https://www. 
researchgate.net/file.PostFileLoader.html?id=57 $5 \mathrm{fcb} 0 \mathrm{a} 217 \mathrm{e} 200 \mathrm{cb} 31 \mathrm{~d} 2 \mathrm{f} 1 \mathrm{f} \&$ assetKey $=\mathrm{AS}: 37280$ 7700631552@1465895690276. [01 Juni 2018].

Myers SC. 2001. Capital structure. Journal of Economic Perspectives 15(2): 81-102. https:// doi.org/10.1257/jep.15.2.81.

Noor T, Sinaga B, Maulana TBNA. 2015. Testing on pecking order theory and analysis of company's characteristic effects on emitten's capital structure. International Journal of Business Research and Management 1(2): 81-89.

Prabansari Y, Kusuma H. 2005. Faktor-faktor yang mempengaruhi struktur modal perusahaan manufaktur go publik di Bursa Efek Jakarta. Sinergi, Edisi Khusus Finance 1(1): 1-15.

Rehman AU, Wang M, Yu H. 2016. Dynamics of financial leverage across firm life cycle in Chinese firms: an empirical investigation using dynamic panel data model. China Finance and Economic Review 4(19): 1-22. https://doi. org/10.1186/s40589-016-0041-z.

Titman S, Wessels R. 1988. The determinants of capital structure choice. Journal Finance 43(1): 1-21. https://doi.org/10.1111/j.1540-6261.1988. tb02585.x.

Walker MM. 2000. Corporate take over, strategic objectives, and acquiring firm shareholders wealth. Financial Management 29(1): 36-46. https://doi.org/10.2307/3666361.

Warmana GO, Widnyana IW. 2016. Determinan dan kecepatan penyesuaian struktur modal perusahaan pada sektor pertanian di bursa efek indonesia. Jurnal Agrimeta 6(12): 10-17.

Wijayanti AD. 2012. Pengaruh struktur kepemilikan dan life cycle perusahaan terhadap kebijakan pembiayaan pada perusahaan manufaktur yang terdaftar di Bursa Efek Indonesia [tesis]. Jakarta: Universitas Indonesia. 